\title{
Participation and Voting Behavior of Poles Abroad in Home Country Elections. The Case of Poles in the US and Canada in Comparative Perspective
}

The article offers an analysis of an important aspect of trans-national politics: the electoral participation of Polish citizens abroad in the national elections in Poland. The author presents a comparative analysis of the data regarding the elections (both parliamentary and presidential) that took place in Poland in the last two decades (1990-2015), together with major trends, distribution of votes and their possible impact on general election results. The analysis reveals interesting dynamics of electoral mobilization of Polish emigrants, points out possible factors contributing to the level of electoral participation and shows political preferences of Polish voters in the US and Canada in comparative perspective.

Keywords: external voting, electoral participation, Polish diaspora in the US and Canada

\section{Introduction}

As a result of the successive waves of mass emigration taking place in the last two centuries, Polish diaspora constitutes a large population. First numerous outflows date back to the mid-19th century, followed later by emigration, mostly to the USA and Western Europe, induced by political oppressions and slow economic development. As a result "a diaspora of workmen and a diaspora of victims" was formed (Walaszek 2001: 10-16). A significant trend in the history of Polish emigration was

${ }^{1}$ Contact: m.lesinska@uw.edu.pl tions. The Case of Poles in the US and Canada in Comparative Perspective, Studia Migracyjne - Przeglad Polonijny, 4 (170), p. 97-117. 
the mass outflow after the accession of Poland to the EU and opening the labour markets to the citizens of new member states. So called post-accession wave was an unparalleled phenomenon not only because of its magnitude and dynamics, but also because of its character, which was very unlike the previous post-war waves (Grabowska-Lusińska, Okólski 2009). The Ministry of Foreign Affairs (MSZ) assesses that the size of Polish diaspora is between 16-20 million people, with over 11 million in North America, 4.2 million in Western Europe, and nearly one million in the postSoviet countries. What is important, these numbers refer mostly to persons of Polish origins (next generations of emigrants and kin-minorities) (MSZ 2015). According to the latest estimates of Central Statistical Office in Poland (GUS), at the end of 2016 approximately 2.5 million of Polish citizens stayed abroad for more than 3 months (it is ca. 6\% of national population) (GUS 2017). It means that there is quite large population of voters who are eligible to participate in national elections in Poland.

Since 1960s Polish citizens were entitled to vote from abroad; in practice, however, this opportunity was used mainly by the staff of diplomatic and military missions as well as posted workers (Lesińska 2014b:26-27). For the first time, largescale mobilization of Polish diaspora to participate in national elections occurred in June 1989, during the first (partially free) elections which became a symbolic starting point of Poland's democratization (Lesińska 2016a). The current external voting legislation was developed in early 1990s, however some important modifications were introduced in the last decade, including simplification of registration process and implementation of correspondence voting.

This article presents the analysis of electoral participation of Polish diaspora in national elections in Poland in the years 1990-2015 and its determinants, with special attention to Polish citizens living in the US and Canada. The article consists of four main parts, the first being an overview of the research studies dedicated to external voting and the factors influencing the political engagement of citizens residing abroad. The second presents the general overview of legislation and institutional framework in Poland related to organization of national elections abroad. Next, the dynamics of participation of Poles abroad in presidential and parliamentary elections in the last twenty five years is presented, together with major trends, distribution of votes and their possible impact on election results. The last part of the article focuses on electoral participation and political preferences of Polish voters in the US and Canada which are compared with voting behavior of Poles in the UK and Ireland, and with voters in Poland. The article is based on thorough analysis of data from the State Election Commission (described in the text as "PKW archive"), literature and documents gathered during the author's individual research ${ }^{2}$.

2 The article includes major findings of a study conducted within the project "Electoral participation of Polish diaspora in the state elections since 1989" founded by National Centre of Science (no DEC2011/03/D/HS5/01055). 


\section{The determinants of electoral participation among citizens voting from abroad}

There are two main approaches in the scientific studies dedicated to electoral participation of citizens voting from abroad. The first represents the country of origin perspective and focuses primarily on the organization of the electoral system, voting procedures as well as the reasons and effects of the political empowerment of the diaspora (e.g. Ellis et al. 2007; Bauböck 2007; Lafleur 2013). The second concentrates on the profile of voters, their political behavior, level of the electoral participation and its determinants (e.g. Boccagni 2011; Ciornei, Østergaard Nielsen 2015; Itzigsohn, Villacrés 2008).

Three main groups of factors that affect the level of participation of citizens voting from abroad is identified in the literature: 1) political (presence of political parties abroad, inclusion of issues related to diaspora in political programs and election campaigns, political culture of the country of origin which determines the level of trust in home country politics); 2) institutional (registration and voting procedures, type of election in which emigrants are allowed to participate, available methods of voting - in person, by post, etc.); 3 ) socio-economic and demographic profile of citizens abroad (age, gender, occupation, income, education, legal status in the country of residence, etc.) (Lafleur 2013: 110-115).

There is still limited number of case studies related to electoral participation of citizens residing abroad. The comparative research of Irina Ciornei and Eva Østergaard Nielsen (2015) on external voting of four emigrant populations (French, Italians, Romanians and Croats) confirms that the following factors influence external turnout: registration and voting procedures (the simpler, the better, including the opportunity to vote by post), the electoral campaigns and engagement of political parties in issues related to diaspora, and geographical and political distance (emigrants who reside in EU countries turned out to be more likely to vote in home country elections than their co-nationals outside the EU). Moreover, existing studies indicate proportionally much lower level of the electoral engagement of citizens voting from abroad in comparison to voters in the country (see Itzingsohn, Villacres 2008; Lafleur 2013; Tintori 2011). The length of stay abroad also occurs to be an important determinant. Quantitative analysis of Latino National Survey data show that the longer the period abroad, the lower the interest of emigrants in elections in the country of origin, which may be associated with less and less interest in domestic politics in home country, and deeper integration with the host society (Waldinger et al. 2012). In addition, the study of Tunisian migrants presents that the level of participation in election varied significantly among the destination countries where different profiles of emigrant populations reside (in the US and Canada which attracts highly skilled Tunisians the level of participation in home 
elections is much higher than in European countries where low skilled workers dominate in Tunisian population) (Jaulin 2015).

The socio-economic profile of voters and self-organization of migrant population also matter. The existing studies indicate that men, younger and better educated persons with stable employment and legal status in the country of residence are more likely to vote in the elections in home country (Jaulin 2015; Lafleur, Sanchez-Dominguez 2015). The social capital of emigrants, including their organizational structure and the frequency and intensity of their contacts with the country of origin, as well as local dynamics within diaspora communities also play an important role in supporting electoral engagement. Organizations representing diaspora often have connections with political parties in the country of origin, organize meetings with candidates or political debates during the election campaigns. To conclude, various factors, deriving from the political system of country of origin on the one hand and the characteristics of migrant population, on the other, determine electoral participation of citizens living abroad.

\section{An overview of external voting legislation and institutional framework in national elections in Poland}

The states that recognize electoral rights and allow for participation of citizens residing abroad in the elections are not only spread all over the world, but are also very diverse in terms of political systems, level of economic development as well as history of emigration and size of diaspora (Ellis et al. 2007). Michael Collyer (2014: 68) analyzing the external voting systems in various countries classified them into three main groups. The first includes the countries that allow citizens living abroad to take a part in the elections, provided that they vote on its territory (what means that they must travel to the home country to vote, e.g. Albania). The second group consists of countries that organize constituencies outside their borders (where external voting is implemented). The third contains the countries where there is a pool of seats in the parliament reserved for representatives of the diaspora, which are elected by voters residing abroad (e.g. France, Italy or Croatia).

Poland belongs to the second group presented above. Polish citizens while living abroad, no matters if they live outside Poland permanently or only temporarily, are entitled to vote in parliamentary and presidential elections, in elections to the European Parliament and in referendums ${ }^{3}$. The only requirements include age threshold (eighteen years or more on the day of the elections) and Polish

\footnotetext{
${ }^{3}$ Initially, citizens residing abroad could only participate in the first round of presidential elections, this was changed in 2000 and since then Polish citizens abroad could vote for President in both rounds.
} 
nationality (confirmed by valid Polish passport or ID document when voting in an EU country). It is also obligatory to enroll in advance (three days before election day at the latest) to the Register of Voters abroad, at an appropriate consulate or by filling online application. Moreover, Polish citizens abroad are also eligible to run as candidates in national elections (parliamentary and presidential).

Poles can cast votes from abroad in national elections by voting in person or by correspondence ${ }^{4}$. In 2011, when voting by post was introduced, only 16 thousand people (13\% of all registered voters abroad) used this option (PKW archive). The last elections showed the increasing interest in this method of voting. In 2015 presidential elections, 34 thousand voters cast their ballot by post in the first and 44 thousand in the second round (17\%). In the parliamentary elections taking place in the same year the number raised to 35 thousand (20\%). It seems that correspondence voting is getting more and more popular, mainly because of the growing dispersion of Polish communities abroad and limited access to the polling stations.

One of the factors that may affect the level of electoral participation is the number of polling stations abroad ${ }^{5}$. Their number and distribution in different countries have changed significantly over time. In 1990 elections 177 polling stations were established abroad, in the next elections their number was much smaller (the lowest ever was in parliamentary elections in 1993 - 117). During the elections of 2005 national and foreign media showed long queues of Polish voters waiting in front of the consulates (in the UK and Ireland particularly) which in turn piqued politicians' attention (Sześciło 2007). In a short time, the number of polling stations abroad was significantly increased, in 2007 elections to 205, and in 2011 reached its historical record - 268 (PKW archive). Nevertheless, it has to be stressed that when voting by post is possible, the number of polling stations cannot be considered as a serious obstacle in electoral participating process. Taking into account the current regulations and practices, the procedures implemented and the organization of elections abroad should be assessed as voter-friendly.

\footnotetext{
${ }^{4}$ Voting by mail ballot required earlier registration, the voter abroad needed to apply fifteen days before the election or ten days before the second round of presidential elections. Having received the voting package by post, the voter had to fill it and sent back to the consulate, where it was opened on the election day in the presence of an electoral commission and added to all the other votes cast there. What is important, if the voter forgot to send a ballot by post, the electoral code provided the possibility of delivering the completed electoral package directly to the consulate before or on the election day. The electoral law was changed in January 2018, since then the correspondence mode of voting is limited only to disabled persons.

${ }^{5}$ The list of the polling stations established abroad is set up by Ministry of Foreign Affairs (in consultation with the State Election Commission) before every elections.
} 


\section{Participation of Poles residing abroad in national elections in Poland (1990-2015)}

In the years 1990-2015, there were eight parliamentary and six presidential elections in Poland. The level of participation of Poles voting from abroad has been changing over time. In the first fully free elections (presidential in 1990) more than 143 thousand Poles registered themselves to vote abroad and almost $80 \%$ of them (113 thousand) cast the vote. In the subsequent elections until 2005, the level of participation of Poles abroad remained much lower. The lowest number of registered voters and votes cast abroad was recorded in parliamentary elections in 2001 (respectively 41 thousand and 26 thousand) (PKW archive). With mass emigration related to Poland's accession to the European Union in 2004, there has been a notable increase in the number of Poles residing abroad and, at the same time, those entitled to vote outside the country ${ }^{6}$.

As a result, dynamic growth in number of voters abroad in the years following the EU accession was registered, in particular in the elections of 2007 and 2010. The highest level of electoral participation of Poles abroad ever was recorded in the second round of presidential election in 2010 when more than 277 thousand voters were registered and more than 203 thousand cast the votes. In the parliamentary elections in 2011, the number of votes decreased noticeably (to 119 thousand), but in the last (double) elections in 2015, slight increase was recorded again (PKW archive). The registered voters and votes cast abroad in last 25 years are presented below (see Figure 1 and Table 1).

What is particularly interesting, the increase in the number of post-2007 registrations and votes was noticeable not only in the main destination countries of post-accession migration (such as Ireland, Norway or Spain), but also in those countries where the number of Poles was traditionally high (like the US or Germany). In 2007, the number of people who voted abroad was four times higher than in 2005. Similar increase in electoral participation abroad can be observed by comparing the number of votes in the presidential elections of 2005 and 2010. In the second round in 2010, the number of votes cast was four times higher than five years earlier. Even higher dynamics were recorded in numbers of votes cast in particular countries. While comparing participation of Poles in the UK in presidential elections in 2005 and 2010 it occurs that 14 times more people participated (the number of cast votes changed in this period from 3 thousand to 44 thousand), in Ireland eight times more (from 1.5 thousand to 12 thousand), and in Germany almost four times more (5.7 thousand to 21 thousand). In the case

\footnotetext{
${ }^{6}$ According to data from GUS, the number of Polish citizens residing in EU countries for more than 3 months increased from 750 thousand in 2004 to 1.1 million in 2005, 1.6 in 2010 and over 2 million in 2016 (GUS 2017:2).
} 
Figure 1

Registered voters and votes cast abroad in elections in Poland in years 1990-2015

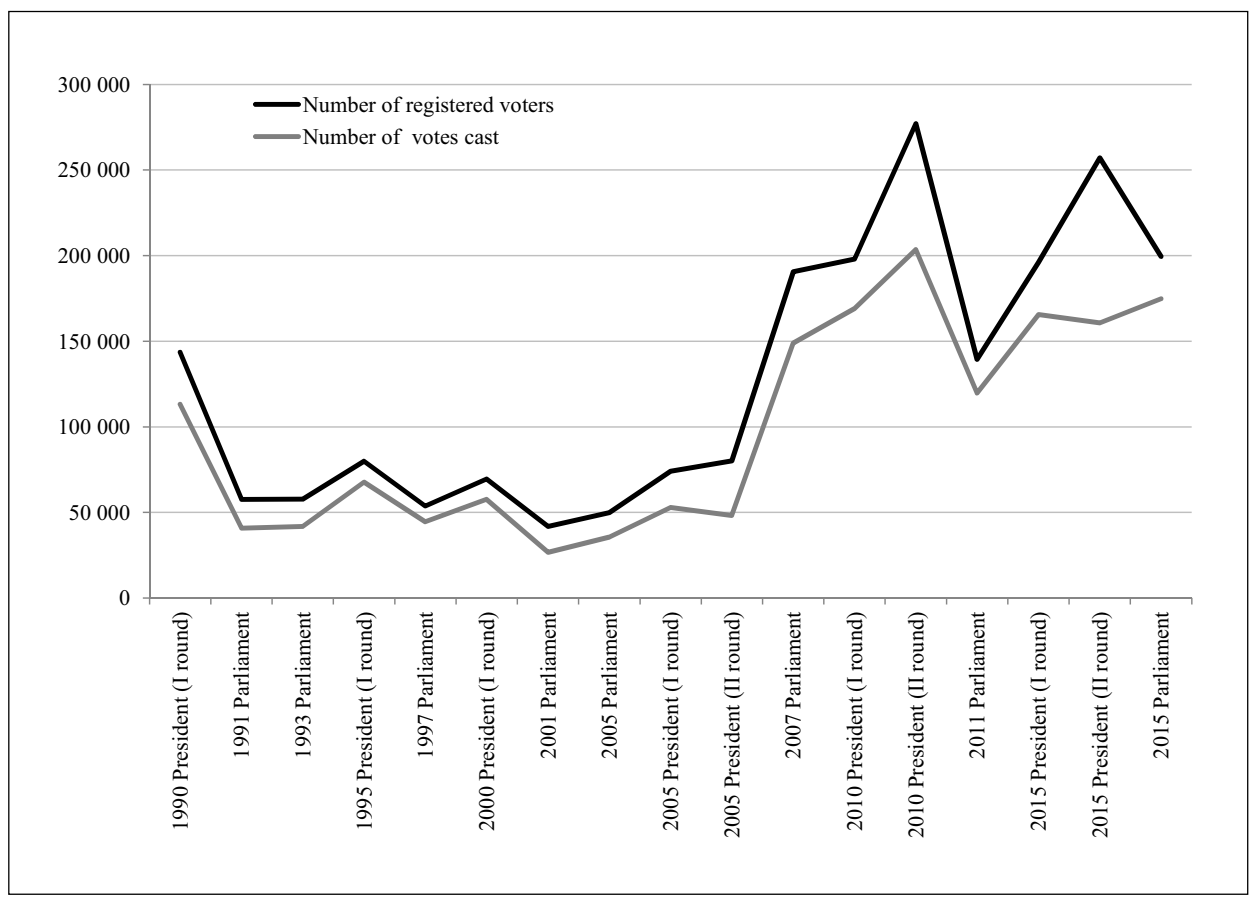

Source: author's elaboration, based on the PKW archive.

of the US and Canada, the change was not so spectacular, but also visible: in the US in both rounds over three times more votes were cast in 2010 than five years earlier (increase from 10 thousand to 33 thousand in the first round and from 9 thousand up to 37 thousand in the second), in Canada the increase was double (from 3 thousand to 6 thousand in the first round and from 2.7 thousand up to 6.7 thousand in the second one). The Figure 2 presents the dynamics of votes cast in selected countries since 2000 .

Countries with the highest level of participation belonged to the group with traditionally large Polish diaspora, such as the US, Germany, France and Canada. In the last 15 years the UK and Ireland joined this group. In the case of the 2007 and subsequent elections, around $60 \%$ of all votes cast abroad were recorded in four countries: the UK, Ireland, the US and Germany (see Table 2). Until 2005, Poles living in the US dominated among Polish voters abroad, in presidential elections of 2000 the share of votes cast in this country reached $32 \%$ of all registered abroad, what means that every third vote from abroad was recorded in the US. A similar high share of votes from the US was registered also in previous elections: $29 \%$ in 
Table 1

The votes cast abroad in parliamentary and presidential elections in Poland (1990-2015)

\begin{tabular}{|c|c|c|c|c|}
\hline Elections & $\begin{array}{c}\text { Number } \\
\text { of persons } \\
\text { registered to } \\
\text { vote }\end{array}$ & $\begin{array}{l}\text { Number of } \\
\text { votes cast }^{\mathrm{a}}\end{array}$ & $\begin{array}{l}\text { Number } \\
\text { of polling } \\
\text { stations } \\
\text { established } \\
\text { abroad }\end{array}$ & $\begin{array}{c}\text { Votes cast } \\
\text { abroad } \\
\text { (as \% of all } \\
\text { votes cast } \\
\text { in elections) }\end{array}$ \\
\hline $\begin{array}{l}1990 \text { Presidential } \\
\text { (1st round) }\end{array}$ & 143586 & 113251 & 177 & 0.67 \\
\hline 1991 Parliamentary & 57648 & 40834 & 156 & 0.34 \\
\hline 1993 Parliamentary & 57870 & 41918 & 117 & 0.29 \\
\hline $\begin{array}{l}1995 \text { Presidential } \\
\text { (1st round) }\end{array}$ & 79896 & 67683 & 127 & 0.37 \\
\hline 1997 Parliamentary & 53848 & 44561 & 144 & 0.49 \\
\hline $\begin{array}{l}2000 \text { Presidential } \\
\text { (1st round) }\end{array}$ & 69625 & 57649 & 167 & 0.32 \\
\hline 2001 Parliamentary & 41817 & 26749 & 165 & 0.19 \\
\hline 2005 Parliamentary & 49840 & 35611 & 161 & 0.29 \\
\hline $\begin{array}{l}2005 \text { Presidential } \\
\text { (1st round) }\end{array}$ & 74115 & 52958 & 162 & 0.35 \\
\hline $\begin{array}{l}2005 \text { Presidential } \\
\text { (2nd round) }\end{array}$ & 80071 & 48179 & 162 & 0.31 \\
\hline 2007 Parliamentary & 190637 & 148946 & 205 & 0.90 \\
\hline $\begin{array}{l}2010 \text { Presidential } \\
\text { (1st round) }\end{array}$ & 198014 & 169053 & 263 & 0.99 \\
\hline $\begin{array}{l}2010 \text { Presidential } \\
\text { (2nd round) }\end{array}$ & 277016 & 203477 & 263 & 1.19 \\
\hline 2011 Parliamentary & 139415 & 119678 & 268 & 0.79 \\
\hline $\begin{array}{l}2015 \text { Presidential } \\
\text { (1st round) }\end{array}$ & 196204 & 165567 & 229 & 1.10 \\
\hline $\begin{array}{l}2015 \text { Presidential } \\
\left(2^{\text {nd }} \text { round }\right)\end{array}$ & 257161 & 160749 & 229 & 0.94 \\
\hline 2015 Parliamentary & 199451 & 174805 & 250 & 1.12 \\
\hline
\end{tabular}

Source: author's elaboration, based on the PKW archive.

a The number of votes includes both valid and invalid votes. 
Figure 2

Number of votes cast abroad in elections in Poland (2000-2015) in selected countries

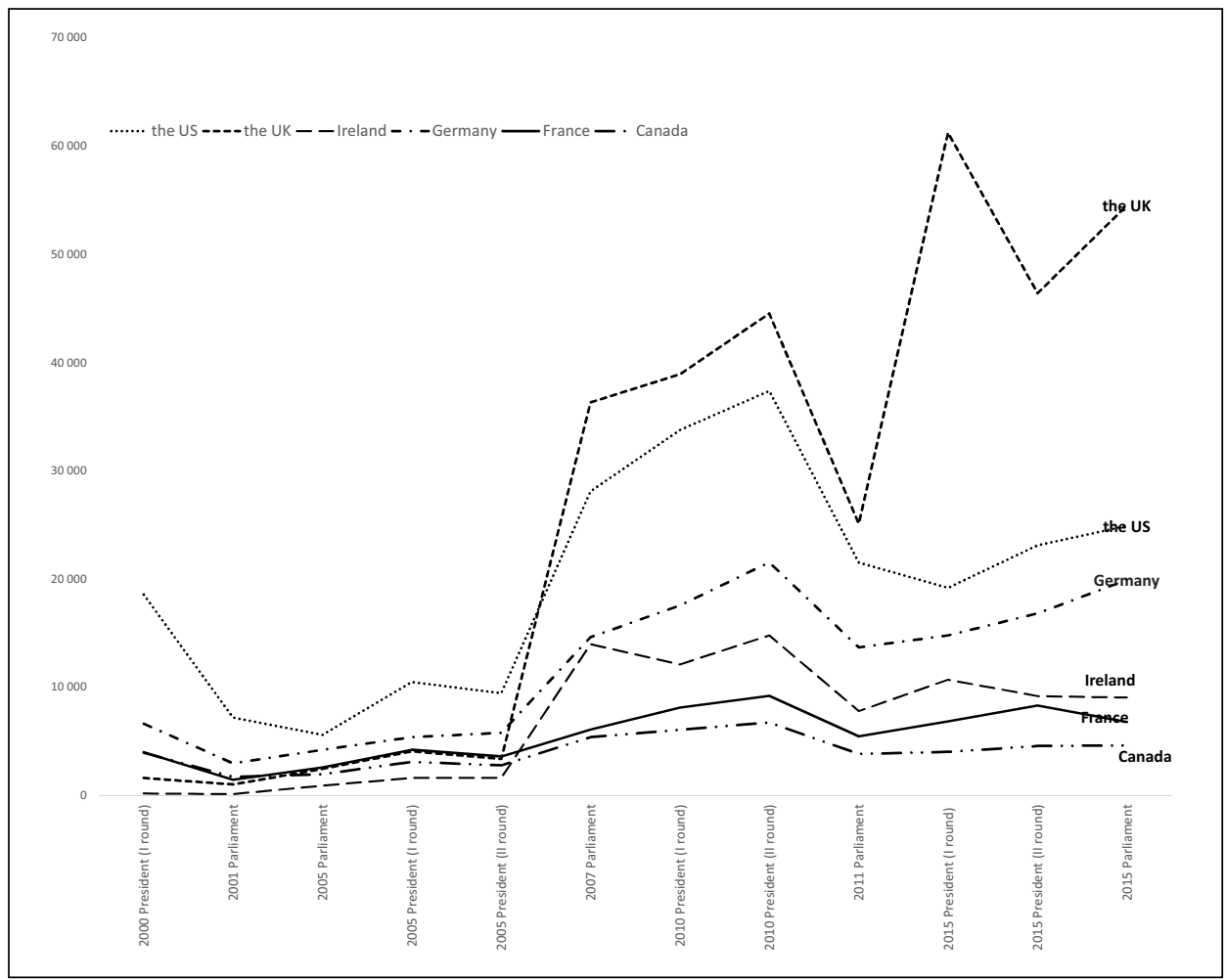

Source: author's elaboration, based on the PKW archive

$1995,28 \%$ in 1997 and $26 \%$ in 2001 . The share of votes cast in these countries has significantly decreased in last two decades: from $32 \%$ to $11-14 \%$ in the US and from $6 \%$ to $2 \%$ in Canada. This shift is a direct consequence of significant number of votes cast in European countries by Poles representing the post-accession wave of emigration. The greatest dynamics was recorded in the case of the UK, where the share of votes cast in this country in the total number of votes from abroad increased from 2\% in 2000 to $36 \%$ in 2015 (PKW archive).

The system implemented in Poland is called "assimilated representation", what means that all the votes cast abroad are added to one voting district in the country (Korzec, Pudzianowska 2013:11). In the parliamentary elections, all votes from abroad are added to Warsaw 1 voting district (which is one from 41 voting districts on Poland's territory and one of the most numerous, with more than 1.5 million inhabitants entitled to vote). The data shows that the votes cast abroad constitute around $1 \%$ of all votes recorded in any Polish national election. What is 
Percentage share in the total number of votes cast abroad in selected countries (2000-2015)

\begin{tabular}{|c|c|c|c|c|c|c|c|c|c|}
\hline & 营 & 总 & 佣 & 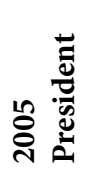 & 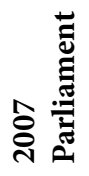 & 苟 & 롤 & 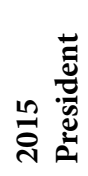 & 일 \\
\hline UK & $2 \%$ & $3 \%$ & $6 \%$ & $6 \%$ & $24 \%$ & $21 \%$ & $21 \%$ & $36 \%$ & $31 \%$ \\
\hline US & $32 \%$ & $26 \%$ & $15 \%$ & $19 \%$ & $18 \%$ & $18 \%$ & $18 \%$ & $11 \%$ & $14 \%$ \\
\hline Germany & $11 \%$ & $11 \%$ & $11 \%$ & $11 \%$ & $9 \%$ & $10 \%$ & $11 \%$ & $8 \%$ & $11 \%$ \\
\hline Ireland & $0.2 \%$ & $0.3 \%$ & $2 \%$ & $3 \%$ & $9 \%$ & $7 \%$ & $6 \%$ & $6 \%$ & $5 \%$ \\
\hline France & $6 \%$ & $5 \%$ & $7 \%$ & $7 \%$ & $4 \%$ & $4 \%$ & $4 \%$ & $4 \%$ & $3 \%$ \\
\hline Canada & $6 \%$ & $6 \%$ & $5 \%$ & $6 \%$ & $3 \%$ & $3 \%$ & $3 \%$ & $2 \%$ & $2 \%$ \\
\hline
\end{tabular}

Source: author's elaboration, based on the PKW archive

a The results of the presidential elections are presented for the first round (the elections of 2000) and for the second round (the elections of 2005-2015).

important, in practice votes cast out of the country are scattered among many parties and candidates. Moreover, the proportional allocation of parliamentary seats to the parties (the so-called d'Hondt rule) adopted in Poland favors large parties effectively blocking the potential influence of votes from abroad. Thus their actual impact on the overall results of the election at the state level is rather marginal. However, the influence of external voting can be noticeable at the level of electoral district in Warsaw. The votes from abroad accounted from 3.5\% (in 2001) to 15.8\% (in 2015) of the votes recorded in Warsaw district. It means that valid votes from abroad could have some impact on the election results in Warsaw and distribution of parliamentary seats assigned to this particular voting district.

\section{Electoral participation and political preferences of Polish voters in the US and Canada in comparative perspective ${ }^{7}$}

For a long time the US and Canada were the most popular destination countries of Polish emigration, however, they lost the supremacy together with Poland's accession to the EU. According to official American statistics (US Census Bureau 2016), the number of people born in Poland and living in the US is estimated

7 The evaluation of political preferences in this article is limited to the group of Polish voters in the US and Canada and obviously does not reflect the political preferences of all Poles residing in these countries. 
close to 0,5 million (424 thousand), and population of persons who declare Polish origin is 9258 thousand (there is no available data how many of them have Polish citizenship). Taking these numbers into account, there is no surprise that among all Poles voting abroad, these residing in the US were for the long time the most numerous group. Canada is the second main country of Polish settlement in North America. According to the most current census data (2016) the number of persons who declared Polish citizenship is 73 thousand (Statistics Canada). Moreover, in the census questionnaire 842 thousand respondents declared Polish ethnic origin (among these 264 thousand claimed Polish origin as first or most important ${ }^{8}$ ). It has to be underlined that emigration from Poland to both countries has been decreasing constantly since 1990s, especially in the period after Poland's accession to the EU when European countries became more attractive destinations for economic emigrants (Fiń 2014: 111; Reczyńska, Soroka 2013:9).

The number of Poles living in the US and Canada who registered and voted in elections in Poland has fluctuated slightly over time. The first free elections after political transformation (presidential elections in 1990) gained high level of interest among Poles in America (in comparison with Poles in other countries): 29 thousand votes were cast in the US and 6 thousand in Canada. In the subsequent elections these numbers were much lower, but from 2007 the level of participation increased again. The highest level of participation was recorded in 2010 presidential elections when 37 thousand votes were cast in the US and 6 thousand in Canada (see Table 3 and 4 ).

It is difficult to estimate precisely what part of the Polish citizens abroad take part in the elections, mostly due to the lack of credible data related to the number of Polish citizens living in particular countries. However, it should be emphasized that the share of the voters in general population of Poles abroad is low. Assuming that the number of Polish citizens in Canadian census is close to reality (73 thousand) is means that in presidential elections in 2010 and 2015 (second rounds) respectively $9 \%$ and $6 \%$ of Poles living in this country actually voted. Due to lack of reliable data on Polish citizens in the US, it is difficult to prepare similar estimation, however - taking into account the number of registered voters and votes cast in this country - it is reasonable assumption that the electoral participation there is also at low level. Some hypotheses could be indicate as possible explanation of the low number of Polish voters abroad: progressive integration with the host countries and less interest in politics in home state, conviction about the lack of influence on election results while voting from abroad. Also unregulated legal status of some part of Polish emigrants residing in the US and Canada might be an important reason of non-voting, because it is often associated with the lack of valid passport without which participation in the election is impossible.

\footnotetext{
${ }^{8}$ A person could report more than one ethnic origin in the census questionnaire.
} 
Table 3

Elections in Poland (1990-2015) - data on votes cast and number of polling stations in the US

\begin{tabular}{|c|c|c|c|c|}
\hline Year / Elections & $\begin{array}{l}\text { Number } \\
\text { of persons } \\
\text { registered } \\
\text { to vote in } \\
\text { US }\end{array}$ & $\begin{array}{l}\text { Number of } \\
\text { votes cast } \\
\text { in the US } \\
\text { (\% share of } \\
\text { votes cast } \\
\text { abroad) }\end{array}$ & $\begin{array}{l}\text { Number } \\
\text { of polling } \\
\text { stations } \\
\text { in the US }\end{array}$ & $\begin{array}{l}\text { Votes cast for political } \\
\text { parties / candidates in } \\
\text { presidential elections (\% of } \\
\text { valid votes cast in the US) }\end{array}$ \\
\hline 1990 Presidential & 29531 & $\begin{array}{l}29258 \\
(25 \%)\end{array}$ & 14 & $\begin{array}{l}\text { L. Wałęsa: } 18829(64 \%) \\
\text { T. Mazowiecki: } 8751(30 \%) \\
\text { S. Tymiński: } 625(2 \%)\end{array}$ \\
\hline 1991 Parliamentary & 9345 & $\begin{array}{l}8480 \\
(21 \%)\end{array}$ & 22 & $\begin{array}{l}\mathrm{UD}^{9}: 2125(25 \%) \\
\text { PC: } 1749(20 \%) \\
\text { KLD: } 1730(20 \%)\end{array}$ \\
\hline 1993 Parliamentary & 7886 & $\begin{array}{l}7656 \\
(18 \%)\end{array}$ & 11 & $\begin{array}{l}\text { UD: } 2342(31 \%) \\
\text { KdRP: } 1008(13 \%) \\
\text { PC: } 914(12 \%)\end{array}$ \\
\hline $\begin{array}{l}1995 \text { Presidential } \\
\text { (1st round) }\end{array}$ & 20325 & $\begin{array}{l}19683 \\
(29 \%)\end{array}$ & 12 & $\begin{array}{l}\text { L. Wałęsa: } 8442(43 \%) \\
\text { J. Olszewski: } 6205(31 \%) \\
\text { A. Kwaśniewski: } 2295(11 \%)\end{array}$ \\
\hline 1997 Parliamentary & 12730 & $\begin{array}{r}12619 \\
(28 \%)\end{array}$ & 17 & $\begin{array}{l}\text { AWS: } 5274(42 \%) \\
\text { ROP: } 4294(34 \%) \\
\text { UW: } 1347(10 \%)\end{array}$ \\
\hline $\begin{array}{l}2000 \text { Presidential } \\
\text { (1st round) }\end{array}$ & 19167 & $\begin{array}{l}18530 \\
(32 \%)\end{array}$ & 21 & $\begin{array}{l}\text { M. Krzaklewski: } 9907 \text { (53\%) } \\
\text { A. Kwaśniewski: } 3489(18 \%) \\
\text { A. Olechowski: } 3429(18 \%)\end{array}$ \\
\hline 2001 Parliamentary & 8438 & $\begin{array}{l}7178 \\
(26 \%)\end{array}$ & 22 & $\begin{array}{l}\text { LPR: } 2275(32 \%) \\
\text { PiS: } 1994(28 \%) \\
\text { SLD-UP: } 996(14 \%)\end{array}$ \\
\hline 2005 Parliamentary & 7373 & $\begin{array}{l}5578 \\
(15 \%)\end{array}$ & 14 & $\begin{array}{l}\text { PiS: } 2252(41 \%) \\
\text { PO: } 1536(28 \%) \\
\text { LPR: } 775(14 \%)\end{array}$ \\
\hline $\begin{array}{l}2005 \text { Presidential } \\
\text { (1st round) }\end{array}$ & 13667 & $\begin{array}{l}10463 \\
(19 \%)\end{array}$ & 15 & $\begin{array}{l}\text { L. Kaczyński: } 6612(63 \%) \\
\text { D. Tusk: } 3051(29 \%) \\
\text { M. Borowski: } 283(2 \%)\end{array}$ \\
\hline $\begin{array}{l}2005 \text { Presidential } \\
\text { (2nd round) }\end{array}$ & 13745 & $\begin{array}{l}9412 \\
(19 \%)\end{array}$ & 15 & $\begin{array}{l}\text { L. Kaczyński: } 6556(70 \%) \\
\text { D. Tusk: } 2781(29 \%)\end{array}$ \\
\hline
\end{tabular}

${ }^{9}$ The abbreviations and names of political parties in Poland present in the text, see Appendix 1. 


\begin{tabular}{|c|c|c|c|c|}
\hline 2007 Parliament & 31800 & $\begin{array}{l}28073 \\
(18 \%)\end{array}$ & 21 & $\begin{array}{l}\text { PiS: } 18343(66 \%) \\
\text { PO: } 7730(27 \%) \\
\text { LiD: } 964(3 \%)\end{array}$ \\
\hline $\begin{array}{l}2010 \text { Presidential } \\
\text { (1st round) }\end{array}$ & 38831 & $\begin{array}{l}33765 \\
(20 \%)\end{array}$ & 28 & $\begin{array}{l}\text { J. Kaczyński: } 23278(69 \%) \\
\text { B. Komorowski: } 8423(25 \%) \\
\text { G. Napieralski: } 790(2 \%)\end{array}$ \\
\hline $\begin{array}{l}2010 \text { Presidential } \\
\text { (2nd round) }\end{array}$ & 48261 & $\begin{array}{l}37363 \\
(18 \%)\end{array}$ & 28 & $\begin{array}{l}\text { J. Kaczyński: } 26491(71 \%) \\
\text { B. Komorowski: } 10514(29 \%)\end{array}$ \\
\hline 2011 Parliament & 24501 & $\begin{array}{l}21491 \\
(18 \%)\end{array}$ & 27 & $\begin{array}{l}\text { PiS: } 14207(67 \%) \\
\text { PO: } 5168(24 \%) \\
\text { Ruch Palikota: } 794(4 \%)\end{array}$ \\
\hline $\begin{array}{l}2015 \text { Presidential } \\
\text { (1st round) }\end{array}$ & 22141 & $\begin{array}{l}19151 \\
(11 \%)\end{array}$ & 22 & $\begin{array}{l}\text { A. Duda: } 12636(66 \%) \\
\text { B. Komorowski: } 2703(14 \%) \\
\text { P. Kukiz: } 2168(11 \%)\end{array}$ \\
\hline $\begin{array}{l}2015 \text { Presidential } \\
\text { (2nd round) }\end{array}$ & 29151 & $\begin{array}{l}23193 \\
(14 \%)\end{array}$ & 22 & $\begin{array}{l}\text { A. Duda: } 18583(80 \%) \\
\text { B. Komorowski: } 4392(19 \%)\end{array}$ \\
\hline 2015 Parliament & 27576 & $\begin{array}{l}24856 \\
(14 \%)\end{array}$ & 32 & $\begin{array}{l}\text { PiS: } 17933(72 \%) \\
\text { PO: } 2590(10 \%) \\
\text { Kukiz'15: } 1293(5 \%)\end{array}$ \\
\hline
\end{tabular}

Source: author's elaboration, based on PKW archive

a The number of votes includes both valid and invalid votes.

As it has already been mentioned, in both countries the significant increase of votes was recorded when the elections of 2005 and 2010 are compared (the number of votes cast in the US and Canada was three times and twice higher respectively). The question appears then, what factors could potentially influence this change? Taking into account the conclusions from other studies presented in the first part of the article, several explanations are possible. Evidently, the changes in voting procedures and organization of the elections, which took place in the recent years, contributed to higher level of participation: simplification of the registration process, more polling stations established abroad and implementation of voting by post. Another explanation relates to growing political polarization of Polish society and political scene which is also reflected in political behavior of Polish diaspora ${ }^{10}$. The third possible factor is linked to the fact that emigration and diaspora became recently politicized, what is particularly noticeable in time of electoral campaigns when political parties and candidates, especially right-wing parties, such as Prawo i Sprawiedliwość (PiS), appeal to Poles abroad in their political programs and statements (Lesińska 2016b:23).

\footnotetext{
${ }_{10}$ The issue of socio-political cleavages within Polish diaspora is more elaborated in Lesińska 2014a.
} 
Table 4

Elections in Poland (1990-2015) - data on votes cast and polling stations in Canada

\begin{tabular}{|c|c|c|c|c|}
\hline Year / Elections & $\begin{array}{l}\text { Number } \\
\text { of persons } \\
\text { registered } \\
\text { to vote }\end{array}$ & $\begin{array}{c}\text { Number } \\
\text { of votes cast } \\
\text { in Canada } \\
\text { (\% share of } \\
\text { votes cast } \\
\text { abroad) }\end{array}$ & $\begin{array}{l}\text { Number } \\
\text { of polling } \\
\text { stations } \\
\text { in the US }\end{array}$ & $\begin{array}{l}\text { Votes cast for political } \\
\text { parties / candidates in } \\
\text { Presidential elections } \\
\text { (\% of valid votes cast } \\
\text { in the US) }\end{array}$ \\
\hline $\begin{array}{l}1990 \\
\text { Presidential }\end{array}$ & 7131 & $\begin{array}{l}6802 \\
(6 \%)\end{array}$ & 3 & $\begin{array}{l}\text { T. Mazowiecki: } 3053(45 \%) \\
\text { L. Wałęsa: } 2777(41 \%) \\
\text { S. Tymiński: } 613(9 \%)\end{array}$ \\
\hline $\begin{array}{l}1991 \\
\text { Parliamentary }\end{array}$ & 2030 & $\begin{array}{l}1942 \\
(4 \%)\end{array}$ & 3 & $\begin{array}{l}\text { UD: } 495(25 \%) \\
\text { PC: } 331(17 \%) \\
\text { KLD: } 224(11 \%) \\
\end{array}$ \\
\hline $\begin{array}{l}1993 \\
\text { Parliamentary }\end{array}$ & 2629 & $\begin{array}{l}2380 \\
(5 \%)\end{array}$ & 4 & $\begin{array}{l}\text { UD: } 798(33 \%) \\
\text { KdRP: } 295(12 \%) \\
\text { BBWR: } 226(9 \%)\end{array}$ \\
\hline $\begin{array}{l}1995 \\
\text { Presidential } \\
\text { (1st round) }\end{array}$ & 6177 & $\begin{array}{l}5978 \\
(8 \%)\end{array}$ & 4 & $\begin{array}{l}\text { L. Wałęsa: } 2394(40 \%) \\
\text { J. Olszewski: } 2193(36 \%) \\
\text { A. Kwaśniewski: } 629(10 \%)\end{array}$ \\
\hline $\begin{array}{l}1997 \\
\text { Parliamentary }\end{array}$ & 4053 & $\begin{array}{l}3847 \\
(8 \%)\end{array}$ & 4 & $\begin{array}{l}\text { AWS: } 2256(58 \%) \\
\text { ROP: } 822(21 \%) \\
\text { UW: } 341(9 \%)\end{array}$ \\
\hline $\begin{array}{l}2000 \\
\text { Presidential } \\
\text { (1st round) } \\
\end{array}$ & 4156 & $\begin{array}{l}3908 \\
(6 \%)\end{array}$ & 4 & $\begin{array}{l}\text { M. Krzaklewski: } 2054(52 \%) \\
\text { A. Olechowski: } 660(16 \%) \\
\text { A. Kwaśniewski: } 632(16 \%)\end{array}$ \\
\hline $\begin{array}{l}2001 \\
\text { Parliamentary }\end{array}$ & 2025 & $\begin{array}{l}1686 \\
(6 \%)\end{array}$ & 4 & $\begin{array}{l}\text { LPR: } 624(38 \%) \\
\text { PiS: } 352(21 \%) \\
\text { SLD-UP: } 220(13 \%)\end{array}$ \\
\hline $\begin{array}{l}2005 \\
\text { Parliamentary }\end{array}$ & 2445 & $\begin{array}{l}1934 \\
(5 \%)\end{array}$ & 6 & $\begin{array}{l}\text { PiS: } 685(36 \%) \\
\text { LPR: } 567(30 \%) \\
\text { PO: } 410(21 \%) \\
\end{array}$ \\
\hline $\begin{array}{l}2005 \\
\text { Presidential (1st } \\
\text { round) }\end{array}$ & 4215 & $\begin{array}{l}3080 \\
(5 \%)\end{array}$ & 6 & $\begin{array}{l}\text { L. Kaczyński: } 2034(66 \%) \\
\text { D. Tusk: } 848(27 \%) \\
\text { M. Borowski: } 65(2 \%)\end{array}$ \\
\hline $\begin{array}{l}2005 \\
\text { Presidential } \\
\text { (2nd round) } \\
\end{array}$ & 4266 & $\begin{array}{l}2753 \\
(6 \%)\end{array}$ & 6 & $\begin{array}{l}\text { L. Kaczyński: } 1959 \text { (71\%) } \\
\text { D. Tusk: } 773(28 \%)\end{array}$ \\
\hline $\begin{array}{l}2007 \\
\text { Parliament }\end{array}$ & 6305 & $\begin{array}{l}5365 \\
(3 \%)\end{array}$ & 6 & $\begin{array}{l}\text { PiS: } 3540(67 \%) \\
\text { PO: } 1375(26 \%) \\
\text { LiD: } 164(3 \%)\end{array}$ \\
\hline
\end{tabular}




\begin{tabular}{|c|c|c|c|c|}
\hline $\begin{array}{l}2010 \\
\text { Presidential } \\
\text { (1st round) }\end{array}$ & 7056 & $\begin{array}{l}6037 \\
(3 \%)\end{array}$ & 7 & $\begin{array}{l}\text { J. Kaczyński: } 4337(72 \%) \\
\text { B. Komorowski: } 1324(22 \%) \\
\text { G. Napieralski: } 80(1 \%)\end{array}$ \\
\hline $\begin{array}{l}2010 \\
\text { Presidential } \\
\text { (2nd round) }\end{array}$ & 9152 & $\begin{array}{l}6710 \\
(3 \%)\end{array}$ & 7 & $\begin{array}{l}\text { J. Kaczyński: } 4867 \text { (73\%) } \\
\text { B. Komorowski: } 1731(27 \%)\end{array}$ \\
\hline $\begin{array}{l}2011 \\
\text { Parliament }\end{array}$ & 4461 & $\begin{array}{l}3797 \\
(3 \%)\end{array}$ & 7 & $\begin{array}{l}\text { PiS: } 2536(66 \%) \\
\text { PO: } 966(25 \%) \\
\text { Ruch Palikota: } 128(3 \%)\end{array}$ \\
\hline $\begin{array}{l}2015 \\
\text { Presidential } \\
\text { (1st round) }\end{array}$ & 4562 & $\begin{array}{l}3984 \\
(2 \%)\end{array}$ & 9 & $\begin{array}{l}\text { A. Duda: } 2232(56 \%) \\
\text { B. Komorowski: } 649(16 \%) \\
\text { P. Kukiz: } 447(11 \%)\end{array}$ \\
\hline $\begin{array}{l}2015 \\
\text { Presidential } \\
\text { (2nd round) }\end{array}$ & 5948 & $\begin{array}{l}4546 \\
(2 \%)\end{array}$ & 9 & $\begin{array}{l}\text { A. Duda: } 3516(77 \%) \\
\text { B. Komorowski: } 1030(22 \%)\end{array}$ \\
\hline $\begin{array}{l}2015 \\
\text { Parliament }\end{array}$ & 5251 & $\begin{array}{l}4587 \\
(2 \%)\end{array}$ & 8 & $\begin{array}{l}\text { PiS: } 3173(69 \%) \\
\text { PO: } 565(12 \%) \\
\text { Kukiz'15: } 222(4 \%)\end{array}$ \\
\hline
\end{tabular}

Source: author's elaboration, based on PKW archive

a The number of votes includes both valid and invalid votes.

Analyzing political preferences of Poles abroad, it is evident that Poles in America support right-wing candidates for President (Lech Wałęsa, Marian Krzaklewski, Lech Kaczyński and Jarosław Kaczyński) ${ }^{11}$. The situation is similar in the case of political parties; these originating from Solidarity movement: Unia Demokratyczna (UD), Porozumienie Centrum (PC) and Akcja Wyborcza Solidarność (AWS), or conservative-right wing parties such as Liga Polskich Rodzin (LPR) and PiS gained substantial number of votes cast by Poles in the US and Canada in every elections since early 1990s.

Political preferences of Polish voters living in the US and Canada differ considerably in comparison with "post-accession" Polish migrants in the UK and Ireland and Poles voting in the country. In the last decade, the dominant divide of the Polish political scene has been shaped by the main two parties: the centrist-liberal Platforma Obywatelska (PO), and the conservative-right PiS. In the 2005 and the 2010 presidential elections, the leaders of these two parties competed in the second round. In both cases the candidates representing PiS (Lech Kaczyński in 2005 and Jarosław Kaczyński in 2010) gained $70 \%$ of votes in the US and $71 \%$ and $72 \%$ in Canada. Meanwhile, candidates from PO (Donald Tusk in 2005 and Bronisław Komorowski in 2010) gained $71 \%$ and $72 \%$ of votes in the UK and $82 \%$ and $83 \%$

11 The only exception in this trend was Tadeusz Mazowiecki who won in Canada in 1990. 


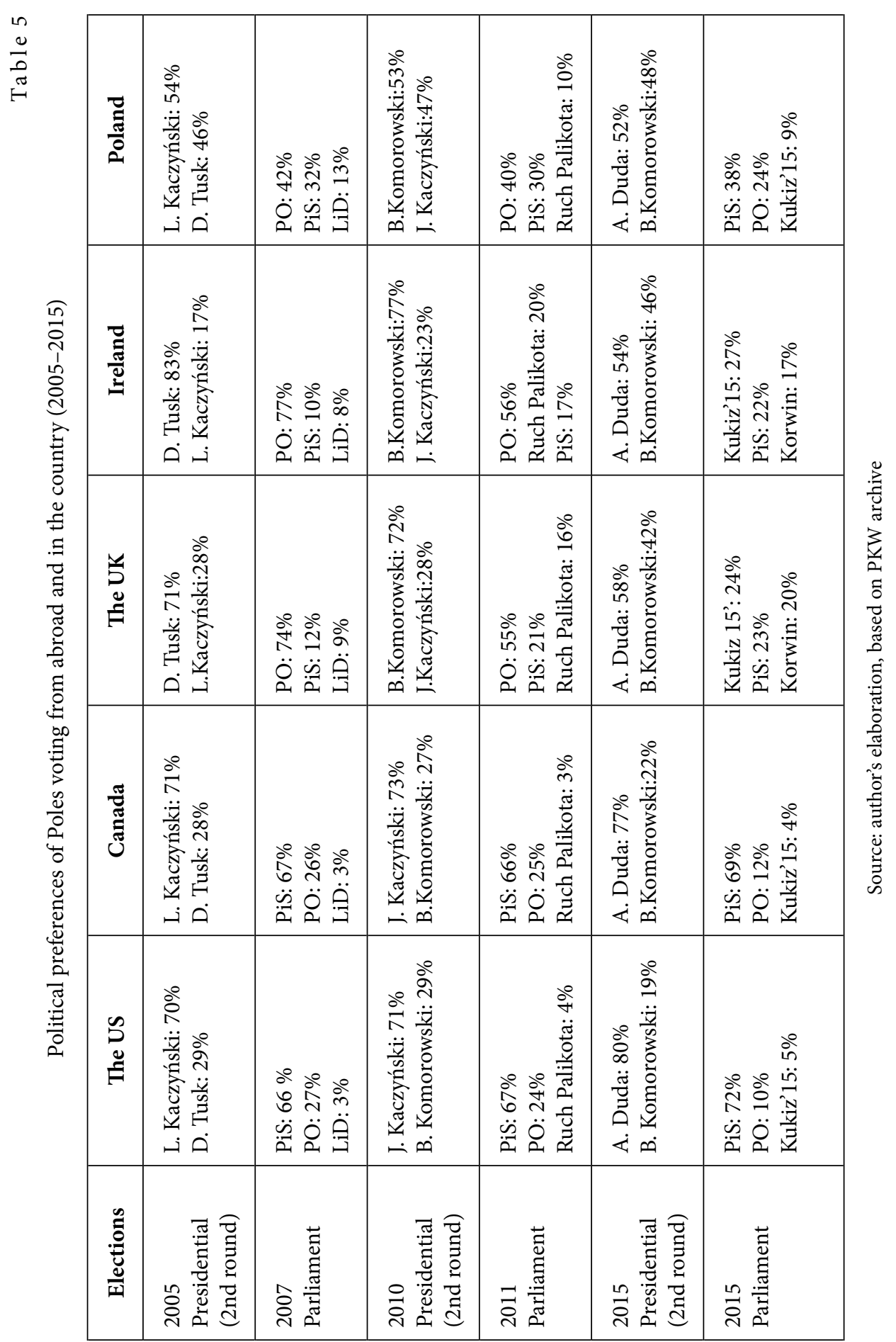


in Ireland (see table 5). Slightly different picture appeared in last presidential election when Andrzej Duda (PiS) received a substantial number of votes not only in America (66\% and $80 \%$ in both rounds in the US, and $56 \%$ and $77 \%$ in Canada), but also in the UK and Ireland (PKW archive) ${ }^{12}$.

A similar distribution of support has emerged in the parliamentary elections. In 2007 the right-wing PiS got 66\% of votes in the US and 67\% in Canada (PO gained $74 \%$ of support in the UK and $77 \%$ in Ireland, and only $27 \%$ in the US and 26\% in Canada). Similar dissemination of votes was in 2011: PiS gained support of $67 \%$ of Poles living in the US and Canada, while PO kept its high result in the UK (57\%) and Ireland (55\%), and much lower in the US (24\%) and Canada (25\%). In the last elections of 2015, this difference was more visible: PiS received $72 \%$ and $69 \%$ of votes cast in the US and Canada, while PO only $10 \%$ and $12 \%$ respectively (PKW archive).

The divergences in voting behavior of Poles residing in the US and Canada, the UK and Ireland (and Poland) could be explained by different profile of Polish migrant population in America and Europe stemming from the cause and time of emigration, length of stay abroad, socio-economic profile and region of origin (Blejwas 1988; Fiń 2014; Garapich 2007). Polish emigrants in America come predominantly from eastern and southern Poland which is traditionally conservative and nationalist part of the country (the Sub-Carpathian region has been the traditional source of emigrants to the US and Canada). This hypothesis is confirmed by other study (Ahmadov, Sasse 2015). The authors analyzed the impact of salient regional divisions in the country of origin on the political cleavages existing among the diaspora, examining the participation of Polish and Ukrainian citizens voting abroad in the presidential elections. Using the logical regression model, they confirmed the hypothesis that the region of origin of emigrants determines their political choice (support of a specific political party or presidential candidate), and the divisions existing among voters in the country are directly reproduced among the diaspora and even strengthened during their stay abroad.

What is also important, Polish Americans have been strongly identified with national culture, its folk and religious elements in particular. In the literature dedicated to Polish diaspora in America it is described as active, politically-conscious group which emphasizes its role as a supporter of the Polish sovereignty (which has been a main political slogan of right-wing parties until today) (JaroszyńskaKirchmann 2004; Pienkos 1991; Znaniecka Lopata 1994). As Grzegorz Babiński (2009:352) noticed, there has been a complete structural assimilation of successive generations of Poles in the US with the exception of the latest emigration waves,

12 Also another radical right-wing candidate Grzegorz Braun noted significant support of Polish voters in America (much higher than in other countries or in Poland). In the first round of presidential elections in 2015 he received $10 \%$ of votes in Canada and $4 \%$ in the US. 
but still their relation to the mother country is based on deeply rooted historical and nationalistic sentiments. Nowadays the tradition of political engagement in domestic politics is still continued by some Polish organizations in US and Canada; they uphold strong relations (both institutional and personal) with right wing political parties in Poland and with Catholic Church organizations (Kasprzyk 2013; Wojdon 2008). The post-accession wave, on the other hand, consists of young people, unburdened by history, appreciative of Poland's accession to the $\mathrm{EU}$, supporting economic reforms, but also critical to political establishment and traditional political system ${ }^{13}$.

\section{Conclusions}

Studies on electoral participation of citizens voting from abroad show that the level of participation as well as voting behavior depend on variables related to socio-economic profile of voters (age, social position, region of origin, length of time abroad, political culture) and legal-institutional variables (legal status in the country of residence, voting procedures as well as political parties' mobilization and polarization of political scene).

Comparing with other countries, Poland not only guarantees to citizens residing abroad the right to participate in elections, but also there is a tendency to widen the scope of electoral rights, such as facilitating the participation in elections by simplification of registration and implementation of correspondence voting. The voting system abroad, which is currently in force in Poland, can be defined as voter-friendly and universal one (as concerning the presidential, parliamentary and referendum elections). While the numbers of voters are small and allocated to one voting district in the capital city, their potential impact on the general results of the elections abroad is modest at best. Yet, it may have potential impact on the distribution of parliamentary seats at the level of Warsaw voting district among the candidates.

The level of participation of Polish voters abroad has fluctuated over time. A closer look at the level of participation of Poles living abroad in national elections shows interesting dynamics in the recent years which are noticed not only in destination countries of post-accession emigration, but also in traditional settlements such as the US and Canada. Three possible explanations of this phenomenon were suggested: simplification of voting procedures, increasing political polarization of

${ }^{13}$ That could be an explanation of high support for populist and anti-system candidates such as Paweł Kukiz or Janusz Korwin Mikke and their parties in the UK and Ireland. Paweł Kukiz won in 2015 presidential election gaining 38\% of all votes cast outside Poland in the first round, with the highest support in the post-accession destination countries: the UK (53\%), Ireland (57\%) and Norway (51\%). 
Poles in the country as well as abroad, and, last but not least, politicization of emigration and diaspora issues in Poland noticeable during electoral campaigns in the recent years. The analysis of political preferences of Poles living in the US and Canada shows that they overwhelmingly voted for right-wing parties and candidates, which gained much higher support in America than in European countries and in Poland. The differences in voting behavior of Poles voting from abroad could be justified by different profile of Polish population in America and Europe related to, among others, cause and time of emigration and region of origin.

\section{Bibliography}

Ahmadov A.K., Sasse G. (2015), Migrants' Regional Allegiances in Homeland Elections: Evidence on Voting by Poles and Ukrainians, "Journal of Ethnic and Migration Studies" vol. 41, issue 11, pp.1769-1793.

Babiński G. (2009), Polonia w USA: na tle przemian amerykańskiej etniczności, Kraków: Oficyna Wydawnicza AFM.

Bauböck, R. (2007), Stakeholder Citizenship and Transnational Political Participation: a Normative Evaluation of External Voting, "Fordham Law Review" no 75, pp. 2393-2447.

Blejwas, S. (1988), Nowa i stara Polonia: napięcia w społeczności etnicznej, in: Kubiak, H., Kusielewicz, E., Gromada T. (ed.), Polonia amerykańska. Przyszłość i współczesność, Wrocław: Ossolineum, pp. 705-726.

Boccagni P. (2011), Reminiscences, Patriotism, Participation: Approaching External Voting in Ecuadorian Immigration to Italy, “International Migration” 49 (3), pp. 76-89.

Ciornei I., Østergaard Nielsen E. (2015), Emigration and Turnout. Determinants of Non-resident Citizen Electoral Mobilization in Home Country Legislative Elections. [paper presented at the Congress of Association Française de Science Politique (AFSP) 22-24.06.2015, www. congres-afsp.fr/st/st5/st5ciorneiostergaard.pdf, [Accessed: 16.05.2018].

Collyer M. (2014), Inside out? Directly Elected 'special representation' of Emigrants in National Legislatures and the Role of Popular Sovereignty. "Political Geography", no 41 [Accessed: 5.04.2018].

Ellis A. et al. (2007), Voting from abroad. The International IDEA Handbook. International Institute for Democracy and Electoral Assistance, the Federal Electoral Institute of Mexico, https://www.idea.int/publications/catalogue/voting-abroad-international-idea-handbook [Accessed: 12.04.2018].

Fiń A. (2014), Współczesna polska emigracja w Stanach Zjednoczonych: skala, rozmieszczenie przestrzenne, przyczyny wyjazdów, "Studia Migracyjne - Przegląd Polonijny", nr 2, pp. $105-130$.

Garapich M. (2007), Odyssean Refugees, Migrants and Power - Construction of 'Other' within the Polish 'Community' in the UK, in: Reed-Danahay D., Brettell C. (ed.), Immigration and Citizenship in Europe and the U.S. Anthropological Perspectives, New Jersey: Rutgers.

GUS (2017), Informacja o rozmiarach i kierunkach czasowej emigracji $z$ Polski w latach 2004 2016. Warsaw, https://stat.gov.pl/obszary-tematyczne/ludnosc/migracje-zagraniczne-ludnosci/informacja-o-rozmiarach-i-kierunkach-emigracji-z-polski-w-latach-20042016,2,10. html [Accessed: 16.05.2018].

Jaroszyńska-Kirchmann A.D. (2004), The Exile Mission: The Polish Political Diaspora and Polish Americans, 1939-1956. Athens: Ohio University Press. 
Jaulin T. (2015). The Geography of External Voting: The 2011 Tunisian Election Abroad. "TSI Working Paper", no 1. Online: http://seminars.wcfia.harvard.edu/tsi/working-papers [Accessed: 16.05.2018].

Kasprzyk K.W. (2013), Diaspora polska w USA wczoraj i dziś, in: red. Głuszyńska I., Lankosz K., Państwo polskie wobec Polaków w diasporze, Bielsko-Biała: Wyższa Szkoła Administracji.

Korzec P., Pudzianowska D. (2013), Access to Electoral Rights Poland. EUDO Citizenship Observatory, http://eudo-citizenship.eu/admin/?p=file\&appl=countryProfiles\&f=1317-PolandFRACIT.pdf [Accessed: 14.04.2018].

Lafleur, J. M. (2013), Transnational Politics and the State: The External Voting Rights of Diasporas. New York: Routledge.

Lafleur J.M., Sanchez-Dominguez M. (2015). The Political Choices of Emigrants Voting in Home Country Elections: A Socio-political Analysis of the Electoral Behavior of Bolivian External Voters. "Migration Studies", no 3(2).

Lesińska M. (2014a), Reproducing Socio-political Cleavages. The Case of Electoral Mobilisation of the Polish Diaspora, in: Benalbaz C., Flavier H., Gille-Belova O, Jones M. (ed.). Les Migrations Intraeuropéennes à l'aube du XXI siécle. Editions A. Pédone: Paris.

Lesińska M. (2014b), Udział obywateli przebywajacych za granica w wyborach krajowych. Analiza rozwiązań prawnych i organizacji wyborów w Polsce na tle innych krajów, "CMR Working Paper”, nr 78 (136). Warsaw: Centre of Migration Research, http://www.migracje.uw.edu. $\mathrm{pl} /$ publication_type/publikacje-cmr/ [Accessed: 28.04.2018].

Lesińska M. (2016a), Czas przełomu, czas podziałów - polska emigracja a wybory 1989 roku, "Studia Polityczne", nr 3 (43).

Lesińska M. (2016b), Upolitycznienie emigracji i diaspory. Analiza dyskursu politycznego $w$ Polsce w latach 1991-2015, "Studia Migracyjne-Przegląd Polonijny", nr 3.

MSZ (2015), Rządowy program wspótpracy z Poloniq i Polakami za granica w latach 2015-2020. Warsaw: Ministry of Foreign Affairs.

Østergaard-Nielsen, E. (2003), International Migration and Sending Countries: Key Issues and Themes, in: Østergaard-Nielsen, E. (ed.) International Migration and Sending Countries: Perceptions, Policies and Transnational Relations, Basingstoke: Palgrave MacMillan, pp. 3-30.

PKW archive (State Election Commission archive), https://pkw.gov.pl/352_Wybory_i_referenda [Accessed: 3-15.04.2018].

Pienkos, D. E. (1991), For Your Freedom Through Ours: Polish American Efforts on Poland's Behalf, 1863-1991, New York: Boulder.

Reczyńska A., Soroka T. (2013), Polska emigracja do Kanady na przełomie wieków XX i XXI $w$ kontekście kanadyjskiej polityki imigracyjnej, „Studia Migracyjne-Przegląd Polonijny”, nr 3, pp. 5-19.

Statistics Canada (2016), https://www.statcan.gc.ca/eng/subjects/ethnic_diversity_and_immigration/citizenship [Accessed: 12.05.2018].

Sześciło D. (2007), Skąd się wzięty kolejki Polaków za granica 21 października - jak uniknąć błędów w przyszłości? Warszawa: Forum Obywatelskiego Rozwoju, Helsińska Fundacja Praw Człowieka.

US Census Bureau, https://www.census.gov/newsroom/stories/2018/europe-day.html

[Accessed: 12.05.2018].

Walaszek, A. (red.) (2001), Polska diaspora. Kraków: Wydawnictwo Literackie.

Waldinger R., Soehl T., Lim N. (2012), Emigrants and the Body Politic Left Behind: Results from the Latino National Survey, "Journal of Ethnic and Migration Studies", no 38(5), pp. 711 -736 . 
Wojdon J. (2008), “W jedności siła!” Kongres Polonii Amerykańskiej w latach 1968-1988, Toruń: Wydawnictwo Adam Marszałek.

Znaniecka Lopata H. (1994), Polish Americans, New Brunswick: Transaction Publishers.

\section{Appendix}

Abbreviations and names of political parties in Poland present in the text (in alphabetical order, author's translation)

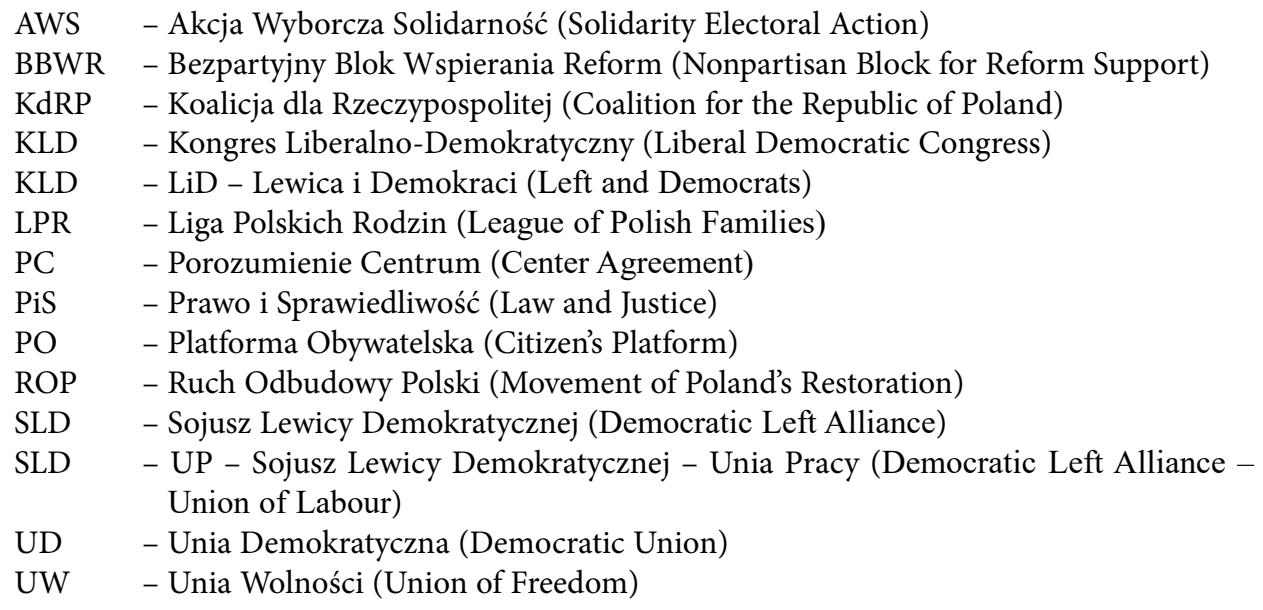

